Vietnam Academy of Science and Technology
Vietnam Journal of Earth Sciences
http://www.vjs.ac.vn/index.php/jse

\title{
General characteristics of rare earth and radioactive elements in Dong Pao deposit, Lai Chau, Vietnam
}

\author{
Nguyen Dinh Chau ${ }^{*}$, Pieczonka Jadwiga ${ }^{1}$, Piestrzyński Adam¹, Duong Van Hao3, \\ Le Khanh Phon', Jodłowski Paweł ${ }^{2}$ \\ ${ }^{1}$ Faculty of Geology, Geophysics and Environmental Protection, AGH University of Science and Tech- \\ nology (AGH UST), al. Mickiewicza 30, 30-059 Kraków, Poland \\ ${ }^{2}$ Faculty of Physics and Applied Computer Science, AGH University of Science and Technology (AGH \\ UST), al. Mickiewicza 30, 30-059 Kraków, Poland \\ ${ }^{3}$ Faculty of Oil and Gas, Hanoi University of Mining and Geology (HUMG)
}

Received 08 December 2016. Accepted 2 February 2017

\begin{abstract}
One of the important rare earth deposits is the Dong Pao localized in Lai Chau province, West-North of Vietnam. Generally, the deposit is composed of two parts, the lower-and the upper. The lower part is composed of dolomite, limestone and intrusive rocks, while the upper part of the profile is represented by a weathered zone containing soil and fragments of mixed barite-fluorite ores. The concentrations of natural radionuclides, chemical compositions of ores, including rare earth elements (REE) in solid samples, were determined by gamma spectrometer equipped with a HPGe detector, laser ablation inductively coupled plasma mass spectrometry (LA ICPMS) and activation method, respectively. In the samples taken from the ore bodies within the weathered zone the REE concentration is about 10 wt.\% and both ${ }^{238} \mathrm{U}$ and ${ }^{232} \mathrm{Th}$ amount to $0.01 \mathrm{wt} . \%$, while in the samples from the hard part of ore the REE and ${ }^{238} \mathrm{U}$ as well as ${ }^{232} \mathrm{Th}$ contents amount only to $0.3 \mathrm{wt} . \%$ and $0.001 \mathrm{wt} . \%$, respectively. So the enrichment of the REE and natural radioactive elements in the deposit is a consequence of the weathering processes. The water samples were taken from the streams, natural tap and thermal water intakes localized in the studied deposit and surrounding region. The ${ }^{238} \mathrm{U},{ }^{234} \mathrm{U},{ }^{228} \mathrm{Ra},{ }^{226} \mathrm{Ra}$ concentrations in the water samples were prepared by the adequate radiochemical procedures and measured using an alpha spectrometer coupled with silicon semiconductor detector and $\alpha / \beta$ liquid scintillation counter. In the stream water, the concentrations of both ${ }^{226} \mathrm{Ra}$ and ${ }^{228} \mathrm{Ra}$ vary from 100 to above $300 \mathrm{mBq} / \mathrm{L}$, while in the natural tap and thermal waters they amount to tens $\mathrm{mBq} / \mathrm{L}$. The concentration of ${ }^{238} \mathrm{U},{ }^{234} \mathrm{U}$ in the thermal water is 80 and $110 \mathrm{mBq} / \mathrm{L}$ respectively, while in the surface water concentrations of uranium isotopes are below 30 $\mathrm{mBq} / \mathrm{L}$.
\end{abstract}

Keywords: REE, natural radionuclides, weathering zone, enrichment, surface and thermal waters, Dong Pao deposit, Lai Chau Vietnam.

C2017 Vietnam Academy of Science and Technology

\section{Introduction}

The rare earth elements (REE) play an

"Corresponding author, Email: Nguyen.Chau@fis.agh.edu.pl increasingly important role in the world economy. REE are implicated in many technologies associated with energy, electronic, nanomaterials, hybrid car components and others. Due to the production of spare parts of hybrid 
cars, wind turbines, battery alloys, magnets, aerospace, the future demand for REE is expected to increase to above 25 times in comparison with the current needs (Hoatson et al. 2011, Curtis 2011, Damascena et al., 2015). What is more in some countries the REE are even treated as economically and politically strategic commodities (Damascena et al., 2015).

Vietnam is a country located in the Indochina Peninsula with the marine coastline extending over more than $1500 \mathrm{~km}$ making beach sands a resource of great REE potential (Hou 2005). Apart from that there are two very rich REE deposits in Vietnam, i.e. Nam $\mathrm{Xe}$ and Dong Pao. Both are located in Lai Chau province, Northwest Vietnam (Kušnir 2010; Pham Ngoc Can et al. 2011). These deposits were discovered in the middle of the XX Century and are continuously investigated (Fromaget 1941; Fromaget \& Saurin 1952; Dovzikov et al., 1965; Le Thac Xinh et al., 1988; Tran Trong Hoa et al., 2010; Pham Ngoc Can et al., 2011), but up to date some problems e.g. 3-4D models still require further examination.

In the scope of the Bilateral Collaborative Project between Hanoi University of Mining and Geology (HUMG) and AGH University of Science and Technology (AGH UST) Kraków, Poland No. 01/2012/HD-HTQTSP, on November 2015 the AGH UST delegation visited Dong Pao REE deposit and performed a geological survey to collect ore samples from both the upper weathered zone and the lower drill core hard rocks from limestone and dolomite sections, and water samples from streams, natural tap waters and thermal spring in the deposit area and its surrounding. The aim of this work is to determine the chemical, rare earth and radioactive element concentrations in the solid samples. The obtained results together with the archival data serve as background to qualify the characteristic parameters of the REE deposit in question.
Water samples were collected and analyzed to characterize the impact of the ores on the local environment, which are responsible for transportation of radioactive elements.

\section{Geological setting}

The Dong Pao Rare Earth deposit is situated in the Northwest Vietnam, within the geographic coordinates of $103^{\circ} 32^{\prime} 37^{\prime \prime}$ $103^{\circ} 33^{\prime} 46^{\prime \prime} \mathrm{E}$ and $22^{\circ} 18^{\prime} 84^{\prime}{ }^{\prime}-22^{\circ} 19^{\prime} 13^{\prime} ' \mathrm{~N}$, occupying an area of about $120 \mathrm{~km}^{2}$ (Le Khanh Phon et al., 2015). From the tectonic point of view this deposit belongs to the Son La-Lai Chau zone bounded in the east by the Red River fault and in the west by the Ma River suture zone (Figure 1). Within the Ma River suture zone there are a few intrusive units such as the Fan Si Pan Massif, Posen batholith and Muong Hum granite. The Fan Si Pan Massif is composed of granites and metagranites separated by narrow intercalations of Neoproterozoic metasediments, mainly mica schists and marbles. In this massif, the youngest igneous unit is the Yensun granite of Paleogene age (Żelaźniewicz et al., 2013). The Precambrian Posen batholith is characterized by the variability in composition of mafic veins. This unit contains also migmatic patches and gneisses (Żelaźniewicz et al., 2013). The Muong Hum unit is characterized by the fine-grained alkali granite and syenite. This suit is poor in $\mathrm{Sr}, \mathrm{P}$, $\mathrm{Ti}, \mathrm{Ba}, \mathrm{Ca}$ but rich in $\mathrm{Rb}, \mathrm{Zr}$, Hf including REE up to $780 \mathrm{ppm}$. Based on geochemical characteristics, Żelaźniewicz and co-workers (2013) suggested that the Muong Hum granite was associated with either continental rifts or mantle plumes.

In the investigated deposit there is the Dong Pao syenite, this formation occupies an area of $8.9 \mathrm{~km}^{2}$ trending NW-SE with length up to $5.5 \mathrm{~km}$. The alkali syenite, porphyritic syenite are the main rocks of the Dong Pao granite, in which the orthoclase (63-92\%), plagioclase $(5-15 \%)$, quartz $(2-20 \%)$, biotite, $(2-6 \%)$ and pyroxene $(0-8 \%)$ are the major minerals, and zircon, apatite and leucite are the minor ones. 
Vietnam Journal of Earth Sciences, 39(1), 14-26
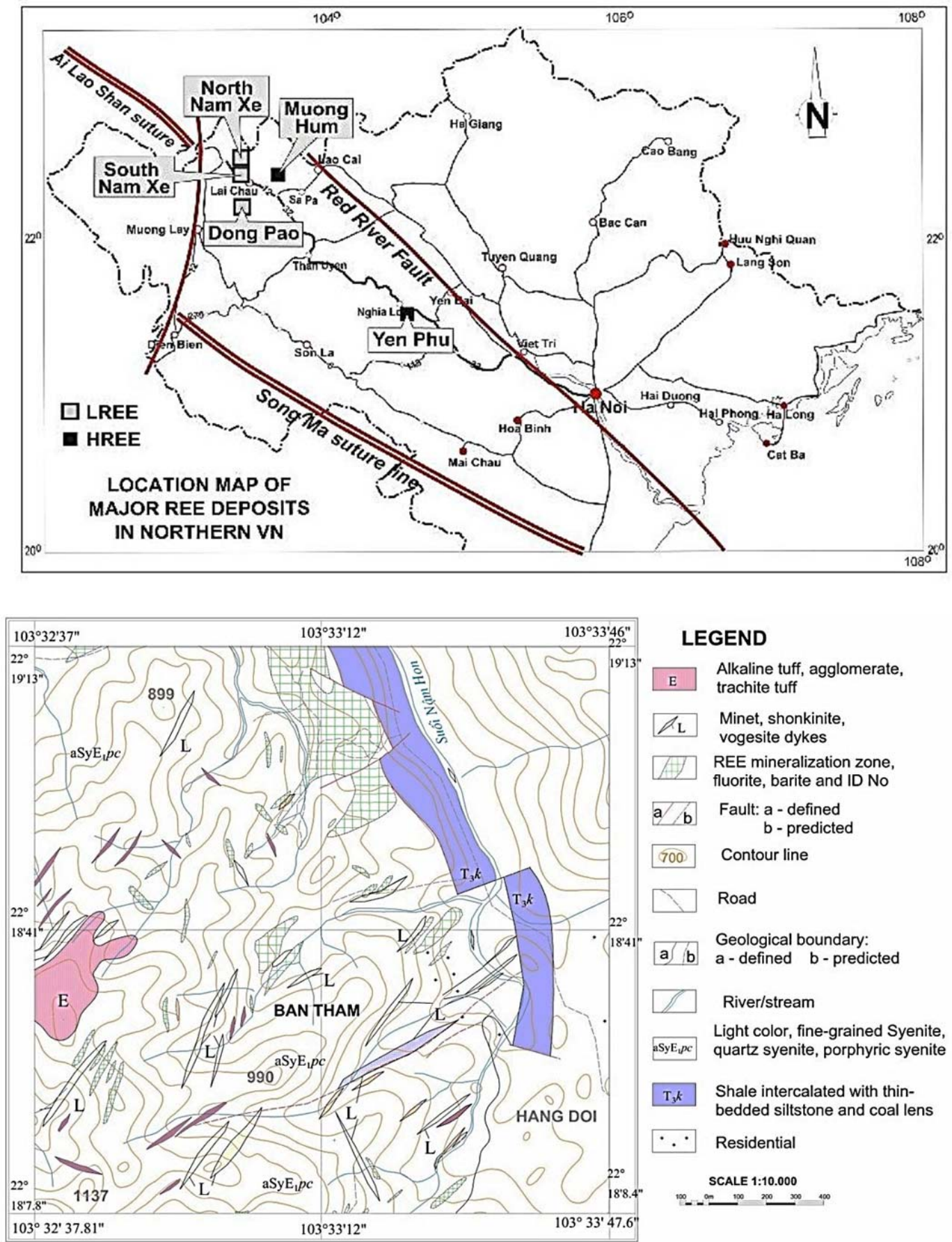

\section{LEGEND}

Alkaline tuff, agglomerate, trachite tuff

Minet, shonkinite, vogesite dykes

REE mineralization zone, fluorite, barite and ID No

a b Fault: a - defined

700 Contour line

Road

Geological boundary:

a) b a-defined b-predicted

River/stream

Light color, fine-grained Syenite, aSyE,pc quartz syenite, porphyric syenite

$\mathrm{T}, k$ Shale intercalated with thinbedded siltstone and coal lens

$\cdot \cdot \cdot$ Residential

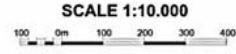

Figure 1. Geological sketch of Dong Pao Rare Earth Deposit on the background of the tectonic sketch of the Indochina block (part of the North-West Vietnam) 
Nguyen Dinh Chau, et al./Vietnam Journal of Earth Sciences 39 (2017)

A sedimentary sequence in the Dong Pao area is composed of Devonian siltstonemudstone formation, Permian limestones, and bauxites, and iron-bearing formations covered conformably by Early and Middle Triassic fine grained grey limestone. These rocks are overlain by the Late Triassic conglomerates and sandstones and in some places with Cretaceous red beds (Tran Van Tri, 2011; Żelaźniewicz et al., 2013; Faure et al., 2014; Halpin et al., 2015). According to Nguyen Tien Du et al., 2011, there are 17 ore bodies in the studied area. The thickness of the ore bodies varies from tens to above $500 \mathrm{~m}$ and length of separate ore bodies vary from 300 to $1000 \mathrm{~m}$. Subcrops of the ore bodies were sampled. The weathered zone is composed of altered fragments of barite-fluorite ores cemented with REE carbonates mixed with clay and $\mathrm{Fe}-\mathrm{Mn}$ hydroxides. In the area, there are many streams flowing along the region relief, the main streams being Nam Hon and Nam $\mathrm{Nu}$. The Nam Hon in the West flows along the trend of rock formations, and in the North, there is the Nam Nu stream crossing near perpendicularly the barite and fluorite bodies in the region. At some places, there are karstic caves, especially there where carbonate formations occur. In the area, the water is re-

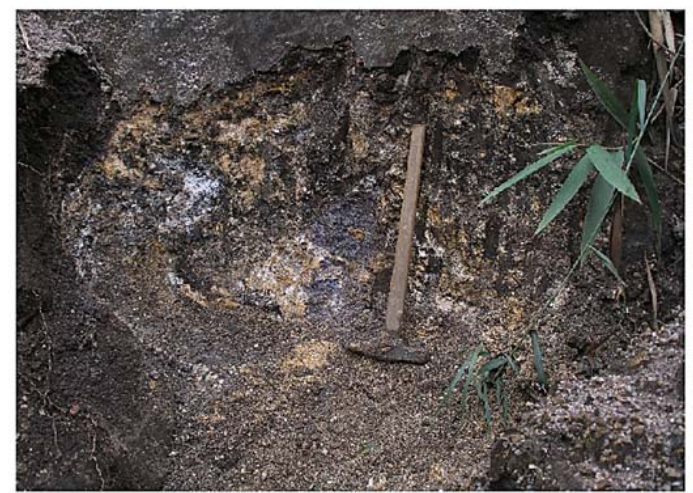

charged from the surface reservoirs and is used by people for daily life and agriculture.

\section{Sampling and analytical methods}

\subsection{Sampling}

After the Conference on the Earth Sciences held at HUMG on November 2015, the AGHUST group made a geological reconnaissance and collected some ore samples P1, P2 in the weathered upper surface soil (Figure 2) and fragments of drill cores KF-133, LK-122 (Figure 3) following the information by geologists working in place. The samples were collected and analyzed to compare results with the existing data of the ore bodies numbered as follows: F4, F7, F9, F10, F14, F16, F17.

The water samples were collected from the Nam Hon (F4), Nam Nu streams (P1), from the thermal spring located $200 \mathrm{~m}$ Southeast from the deposit (TM) and from the artificial concrete container built at the geological office (F9). The tap water in the container is recharged from rain water flowing from the mountain and lead by the bamboo pipes and finally reaches to the cement container; in the paper, this water is defined as natural tap water. All the collected samples were shipped and analyzed at AGH-UST laboratories.

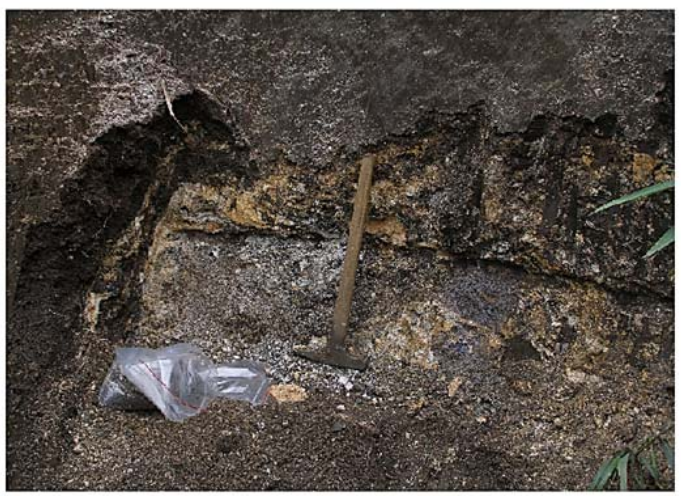

Figure 2. The samples collected from the weathered (upper) zone 

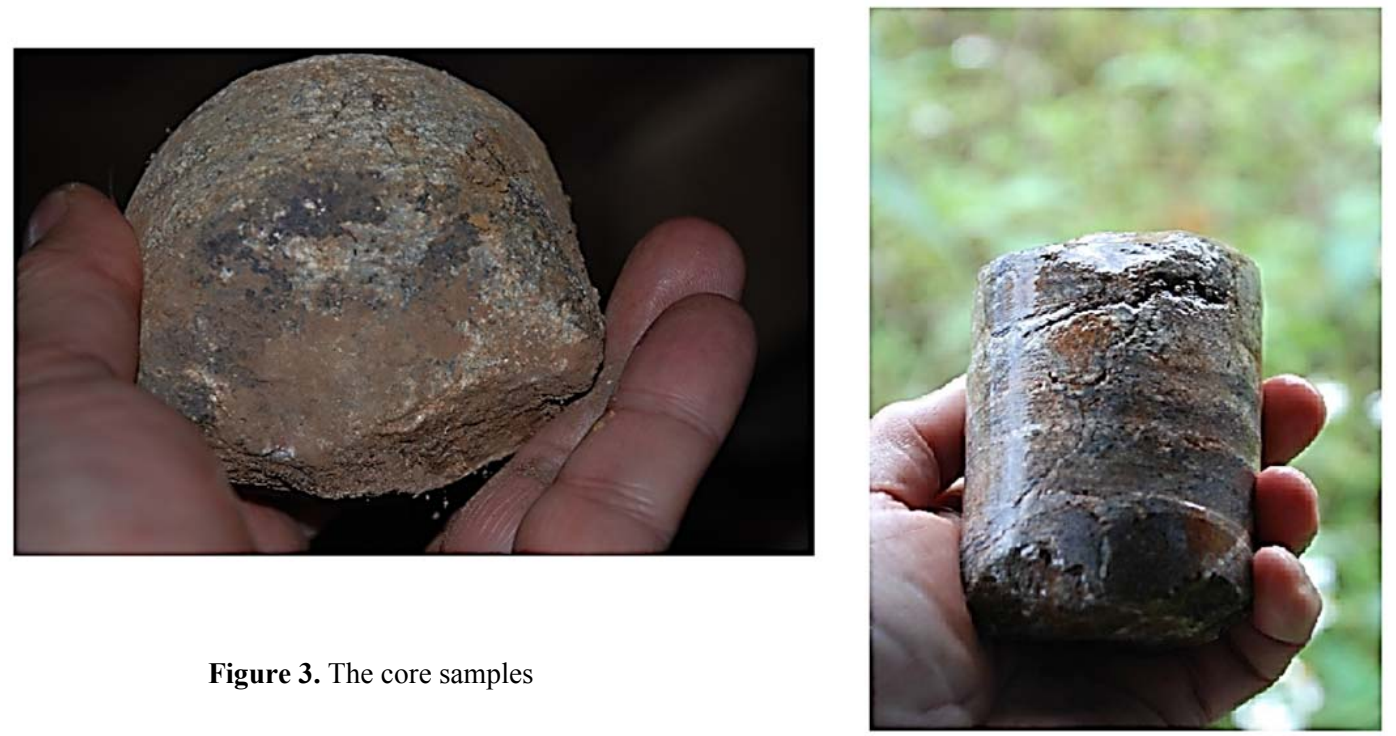

\subsection{Analytical methods}

To determine the chemical and REE composition, the solid samples were sent to $\mathrm{Bu}$ reau Veritas Mineral Laboratories in Vancouver Canada, which possesses the Certificate of Analysis No KRA15000229.1. At the Veritas Mineral Laboratories, the chemical composition of the solid samples is analyzed by laser ablation with induced plasma coupled with the mass spectrometer (LA ICP MS), the REE are analyzed using instrumental neutron activation method (INAA). The LA ICP MS consists in the generation of the fine particles by a laser beam focused on the sample surface, the process known as Laser Ablation. Then the ablated particles are transported to the secondary excitation source of the ICP-MS instrument for digestion and ionization. The excited ions in the plasma torch are subsequently introduced to a mass spectrometer detector for elemental analysis. The LA ICP MS instrument uses the laser wavelength of $193 \mathrm{~nm}$ with $14 \mathrm{~J} / \mathrm{cm}^{2}$ of the power energy density for ablation, in ICP MS the power of $1350 \mathrm{~W}$ for $\mathrm{RF}$ generation, the $14 \mathrm{~L} / \mathrm{min}$ and $0.9 \mathrm{~L} / \mathrm{min}$ argon gas for plasma torch and auxiliary respectively (Liu et al., 2008). The ICP-MS is calibrated using the NIST standard samples of well known chemical composition. The background of the instrumental neutron activation method can be briefly described as follows: an analyzed sample is subjected to a thermal neutron flux and radioactive nuclides are produced. As these radioactive nuclides decay, they emit gamma rays of characteristic energies for each nuclide. Comparison of the intensity of these gamma rays with those emitted by a standard, one can estimate quantitatively the concentrations of the various nuclides.

The sample for gamma measurement was ground until the grains were less than $2 \mathrm{~mm}$ in diameter, then it was dried in an oven at $120^{\circ} \mathrm{C}$ for 24 hours to ensure that moisture was completely removed, then weighted accurately and packed in the aluminum cylindrical Marinelli beaker of $720 \mathrm{ml}$ capacity and sealed to prevent escape of radon. The sealed samples were left for at least 22 days to reach secular equilibrium between the ${ }^{222} \mathrm{Rn}$ and ${ }^{226} \mathrm{Ra}$. The activity concentrations of ${ }^{40} \mathrm{~K}$, ${ }^{226} \mathrm{Ra}$ and ${ }^{232} \mathrm{Th}$ were determined using the gamma-ray spectrometer coupled with HPGe detector of the relative efficiency of $42 \%$ and resolution of $1.9 \mathrm{keV}$ for $1332 \mathrm{keV}$ line and calibrated using the IAEA reference materials RGU, RGTH, RGK as standard samples. The 
gamma lines $609.3 \mathrm{keV}(46.1 \%), 1120.3 \mathrm{keV}$ $(15.0 \%)$ and $1764.5 \mathrm{keV}(15.9 \%)$ from ${ }^{214} \mathrm{Bi}$ were used to determine the activity concentration of ${ }^{226} \mathrm{Ra}$, while that of ${ }^{232} \mathrm{Th}$ were determined from the gamma lines of $911.2 \mathrm{keV}$ $(29.0 \%)$ from ${ }^{228} \mathrm{Ac}$ and $583.0 \mathrm{keV}(30.9 \%)$ and $2614.4 \mathrm{keV}(35.8 \%)$ from ${ }^{208} \mathrm{Tl}$. For ${ }^{40} \mathrm{~K}$, its activity concentration was determined from its $1461 \mathrm{keV}$ gamma line Jodłowski and Kalita (2010).

The chemical composition of the water samples was analyzed using an ICP-AES PerkinElmer Optima 7300 DV spectrometer. The principal of the ICP-AES is similar to the LA ICP MS, but in the ICP-AES the laser ablation is not needed and instead of the atomic mass measurements, the wavelength of the atomic spectral lines is measured. The condition parameters of ICP of both instruments ICP-AES and LA ICP MS are similar. The ICP-AES is calibrated with a multi-element standard solution of the Merck ${ }^{\circledR}$ company.

The uranium isotopes in the water samples were precipitated together with the manganese oxide, then the obtained sample was dissolved in $\mathrm{HCl} 9 \mathrm{M}$ and transmit through the Dowex resin exchange column. The uranium ions were rinsed from the resin column by adding the $\mathrm{HCl} 0.1 \mathrm{M}$ and again precipitated using the neodymium chloride. The precipitate was placed onto the plastic filter of $0.1 \mu \mathrm{m}$ porosity and measured using an alpha spectrometer coupled with silicon PIPs detector. To control the chemical yield and determine the ${ }^{238} \mathrm{U}$ and ${ }^{234} \mathrm{U}$ concentrations, the trace quality amount of ${ }^{232} \mathrm{U}$ solution was added into the studied water sample at the beginning of the chemical procedure (Nguyen et al., 2010).

The radium isotopes were precipitated from the water sample together with barium as the sulfate compound, then the obtained precipitate was cleared up from the other messing isotopes by dissolution it in the EDTA solution. The radium was again precipitated though decreasing $\mathrm{pH}$ sample to 4.5 by adding the acetic acid. The precipitate was washed using distilled water and centrifugal machine, then placed into the special glass vial of $22 \mathrm{~mL}$ and mixed with the gel scintillation cocktail of $12 \mathrm{ml}$. The sample was measured using the Wallac $1414 \alpha / \beta$ Liquid Scintillation counter (Nguyen et al., 1998). The quality of the used methods was tested by comparing many measurements done by several international organizations.

\section{Results and discussions}

Table 1 summarizes the measured oxides of the main metals and some trace elements for the collected solid samples. Table 2 presents the ranges and average concentrations of some oxides of the selected ore bodies reported by Nguyen Tien Du et al., 2011. Comparing the data in both Table 1 and Table 2, we can see that the data presented by this work are contained in the ranges of the data given by Nguyen Tien Du et al., 2011, but all the values of the oxides analyzed by us are comparable with the minimum values in the ranges of the adequate oxides. The calcium, silicon, and iron are principal components of the carbonate rocks. Based on the data of this work, the analyzed oxides in the borehole cores and weathered zone (soil) in the forms of vertical bars are presented in the Figure $4 \mathrm{a}$, $4 \mathrm{~b}$, and $4 \mathrm{c}$. The $\mathrm{Ca}, \mathrm{Mg}, \mathrm{Fe}$ and alkali metals $(\mathrm{Na}, \mathrm{K}, \mathrm{Cs})$ are very vulnerable to weathering processes resulting their concentrations in soil are far lower than that in hard rock by several times, while $\mathrm{Mn}, \mathrm{Ti}, \mathrm{Sc}, \mathrm{Co}$, and $\mathrm{Be}$ are very resistant and enriched to several folds in the weathered zone. According to Rösler and Lange (1972), the weathering degree can be appreciated using the weathering index defined by the formula:

$V_{i}=\frac{\mathrm{CaO}+\mathrm{MgO}+\mathrm{Na}_{2} \mathrm{O}+\mathrm{K}_{2} \mathrm{O}+\mathrm{H}_{2} \mathrm{O}}{\mathrm{SiO}_{2}+\mathrm{Al}_{2} \mathrm{O}_{3}+\mathrm{CaO}+\mathrm{MgO}+\mathrm{Na}_{2} \mathrm{O}+\mathrm{K}_{2} \mathrm{O}}$

The oxides in formula (1) are expressed in mole units, and the weathering index for studied samples is equal to $0.187,0.076,0.731$ and 0.700 for P1, P2, LK122 and KF-133 respectively. 
Vietnam Journal of Earth Sciences, 39(1), 14-26

Table 1. Analyzed concentrations of the metal oxides and trace elements in the collected samples

\begin{tabular}{|c|c|c|c|c|c|c|c|c|c|c|c|c|c|c|c|c|c|}
\hline & $\underline{\mathrm{SiO}_{2}}$ & $\mathrm{Al}_{2} \mathrm{O}_{3}$ & $\mathrm{Fe}_{2} \mathrm{O}_{3}$ & $\mathrm{MgO}$ & $\mathrm{CaO}$ & $\mathrm{Na}_{2} \mathrm{O}$ & $\underline{\mathrm{K}_{2} \mathrm{O}}$ & $\mathrm{TiO}_{2}$ & $\mathrm{P}_{2} \mathrm{O}_{5}$ & $\mathrm{MnO}$ & $\mathrm{Cr}_{2} \mathrm{O}_{3}$ & $\mathrm{Ni}$ & $\mathrm{Sc}$ & $\mathrm{Ba}$ & $\mathrm{Be}$ & $\mathrm{Co}$ & Cs \\
\hline sa & $\%$ & $\%$ & $\%$ & $\%$ & $\%$ & $\%$ & $\%$ & $\%$ & $\%$ & $\%$ & $\%$ & $\overline{\mathrm{ppm}}$ & $\overline{\mathrm{ppm}}$ & ppm & $\overline{\mathrm{ppm}}$ & $\overline{\mathrm{ppm}}$ & $\overline{\mathrm{ppm}}$ \\
\hline P1 & 6.76 & 0.16 & 0.98 & 0.01 & 14.58 & 0.01 & 0.01 & 0.04 & 0.23 & 0.71 & 0.012 & 20 & 4 & 50000 & 2 & 2.2 & 0.1 \\
\hline P2 & 8.23 & 0.23 & 1.94 & 0.01 & 6.27 & 0.01 & 0.01 & 0.07 & 0.39 & 1.13 & 0.011 & 20 & 3 & 50000 & 2 & 4.5 & 0.1 \\
\hline KF-133 & 1.66 & 0.81 & 2.75 & 0.31 & 49.41 & 0.01 & 0.32 & 0.03 & 0.01 & 0.17 & 0.002 & 20 & 1 & 50000 & 1 & 1 & 0.7 \\
\hline LK-122 & 2.37 & 0.07 & 1.99 & 0.16 & 51.52 & 0.01 & 0.02 & 0.02 & 0.85 & 0.16 & 0.002 & 20 & 1 & 16778 & 1 & 1 & 0.1 \\
\hline
\end{tabular}

Table 2. Ranges and average values of concentrations of the metal oxides (\%) in the ore bodies (Nguyen Tien Du et

\begin{tabular}{|c|c|c|c|c|c|c|c|c|}
\hline Ore body & $\mathrm{SiO}_{2}$ & $\mathrm{Al}_{2} \mathrm{O}_{3}$ & $\mathrm{Fe}_{2} \mathrm{O}_{3}$ & $\mathrm{P}_{2} \mathrm{O}_{5}$ & $\mathrm{CaO}$ & $\mathrm{TiO}_{2}$ & $\mathrm{PbO}$ & $\mathrm{ZnO}$ \\
\hline$\overline{\mathrm{F} 4}$ & $\begin{array}{c}5.34-52.8 \\
(22.77)\end{array}$ & $\begin{array}{c}7.08-70.30 \\
(29.56)\end{array}$ & $\begin{array}{c}1.22-12.01 \\
(4.42)\end{array}$ & $\begin{array}{c}0.11-1.12 \\
(0.38)\end{array}$ & $\begin{array}{c}0.06-50.83 \\
(6.86)\end{array}$ & $\begin{array}{c}0.04-1.01 \\
(0.33)\end{array}$ & $\begin{array}{c}0.08-0.97 \\
(0.34)\end{array}$ & $\begin{array}{c}0.02-0.21 \\
(0.06)\end{array}$ \\
\hline F7 & $\begin{array}{c}7.08-70.30 \\
(29.56)\end{array}$ & $\begin{array}{c}0.35-22.64 \\
(8.30)\end{array}$ & $\begin{array}{c}0.98-20.64 \\
(4.82)\end{array}$ & $\begin{array}{c}0.02-1.78 \\
(0.13)\end{array}$ & $\begin{array}{c}0.00-41.43 \\
(6.39)\end{array}$ & $\begin{array}{c}0.04-1.14 \\
(0.37)\end{array}$ & $\begin{array}{c}0.04-0.90 \\
(0.24)\end{array}$ & $\begin{array}{c}0.02-0.34 \\
(0.10)\end{array}$ \\
\hline F9 & $\begin{array}{c}2.02-58.53 \\
(15.70)\end{array}$ & $\begin{array}{c}0.35-27.79 \\
(5.48)\end{array}$ & $\begin{array}{c}1.08-20.94 \\
(3.04)\end{array}$ & $\begin{array}{c}0.02-1.30 \\
(0.12)\end{array}$ & $\begin{array}{c}0.04-41.39 \\
(5.50)\end{array}$ & $\begin{array}{c}0.02-2.11 \\
(0.22)\end{array}$ & $\begin{array}{c}0.06-0.82 \\
(0.29)\end{array}$ & $\begin{array}{c}0.01-0.26 \\
(0.06)\end{array}$ \\
\hline F10 & $\begin{array}{c}1.92-62.22 \\
(24.84)\end{array}$ & $\begin{array}{c}0.40-39.27 \\
(8.41)\end{array}$ & $\begin{array}{c}1.56-12.91 \\
(5.79)\end{array}$ & $\begin{array}{c}0.02-0.63 \\
(0.12)\end{array}$ & $\begin{array}{c}0.04-53.47 \\
(4.48)\end{array}$ & $\begin{array}{c}0.05-1.12 \\
(0.50)\end{array}$ & $\begin{array}{c}0.04-1.39 \\
(0.37)\end{array}$ & $\begin{array}{c}0.02-0.35 \\
(0.11)\end{array}$ \\
\hline F14 & $\begin{array}{c}5.88-42.62 \\
(24.00)\end{array}$ & $\begin{array}{c}1.56-12.96 \\
(6.09)\end{array}$ & $\begin{array}{c}1.19-30.96 \\
(12.65)\end{array}$ & $\begin{array}{c}0.04-4.02 \\
(1.34)\end{array}$ & $\begin{array}{c}0.11-43.60 \\
(7.65)\end{array}$ & $\begin{array}{c}0.05-0.81 \\
(0,33)\end{array}$ & $\begin{array}{c}0.12-1.15 \\
(0.36)\end{array}$ & $\begin{array}{c}0.03-0.45 \\
(0.15)\end{array}$ \\
\hline F16 & $\begin{array}{c}1.29-44.91 \\
(17.19)\end{array}$ & $\begin{array}{c}0.33-21.19 \\
(5.94)\end{array}$ & $\begin{array}{c}3.45-22.13 \\
(10.95)\end{array}$ & $\begin{array}{c}0.20-5.16 \\
(0.92)\end{array}$ & $\begin{array}{c}0.00-32.47 \\
(2.60)\end{array}$ & $\begin{array}{c}0.05-1.10 \\
(0.49)\end{array}$ & $\begin{array}{c}0.09-1.22 \\
(0.46)\end{array}$ & $\begin{array}{c}0.05-0.66 \\
(0.26)\end{array}$ \\
\hline F17 & $\begin{array}{c}20.95-59.06 \\
(46.01)\end{array}$ & $\begin{array}{c}6.75-15.65 \\
(12.93)\end{array}$ & $\begin{array}{c}4.66-16.34 \\
(9.24)\end{array}$ & $\begin{array}{c}0.37-1.77 \\
(0.70) \\
\end{array}$ & $\begin{array}{c}0.00-21.15 \\
(1.33)\end{array}$ & $\begin{array}{c}0.27-0.58 \\
(0.40)\end{array}$ & $\begin{array}{c}0.14-1.30 \\
(0.33)\end{array}$ & $\begin{array}{c}0.04-0.17 \\
(0.07) \\
\end{array}$ \\
\hline
\end{tabular}

In Vietnam, there is the tropical climate, and in the region the intensive vegetable farming resulting in the surface water being rich on $\mathrm{CO}_{2}$, ammonium and the occurrence of a lot of deep fractures in the rocks. The alkaline elements are leached from the rocks by a chemical reaction as follows:

$$
\mathrm{RSiO}_{2}+\mathrm{CO}_{2}+\mathrm{H}_{2} \mathrm{O}=\mathrm{RCO}_{3}+\mathrm{SiO}_{2}+\mathrm{H}_{2} \mathrm{O}
$$

where $\mathrm{R}$ are $\mathrm{Ca}, \mathrm{Mg}, \mathrm{Fe}, \mathrm{Na}_{2}, \mathrm{~K}_{2}, \mathrm{Cs}_{2} \ldots$

The REE concentrations determined for the collected samples and the REE average concentrations of the ore bodies reported by Nguyen Tien Du et al., 2011 are summarized in Table 3 and Table 4 respectively. Both the data and $\Sigma$ LREE/ $\Sigma$ HREE in the Nguyen Tien $\mathrm{Du}$ and co-workers report (2011) are comparable with that of the samples from the upper weathered zone, which can be connected with the fact that the samples presented in the Nguyen Tien Du et al., (2011)'s report were taken from the weathered zone.
The REE concentration in the weathered zone reaches to $10 \mathrm{wt} . \%$, so the studied deposit can be classified to one of the richest REE deposits in the World (Hoatson et al., 2011). The patterns of the REE and radionuclides in the weathered and hard rocks are similar (Figure 5), but their contents in the weathered zone are enriched to near forty fold in comparison to that in the hard rock (Table 4). The ratio ( $\Sigma$ LREE/ $\Sigma$ HREE) in the studied samples ranged from 56 for the hard rock to 121 for weathered one. According to HornigKjargaard, 1998 and Żelaźniewicz et al., 2013, the mentioned phenomena can be explained that at the beginning the rare elements were within the intrusive formations Muong Hum and/or Dong Pao syenite (cf. Figure 1), then they underwent enrichment due to thermal metamorphic processes occurring in the carbonatite formations, so the REE ores were formed as lenses or dykes of various shapes and dimensions. Finely the REE were enriched by the surface chemical weathering processes. 
Nguyen Dinh Chau, et al./Vietnam Journal of Earth Sciences 39 (2017)
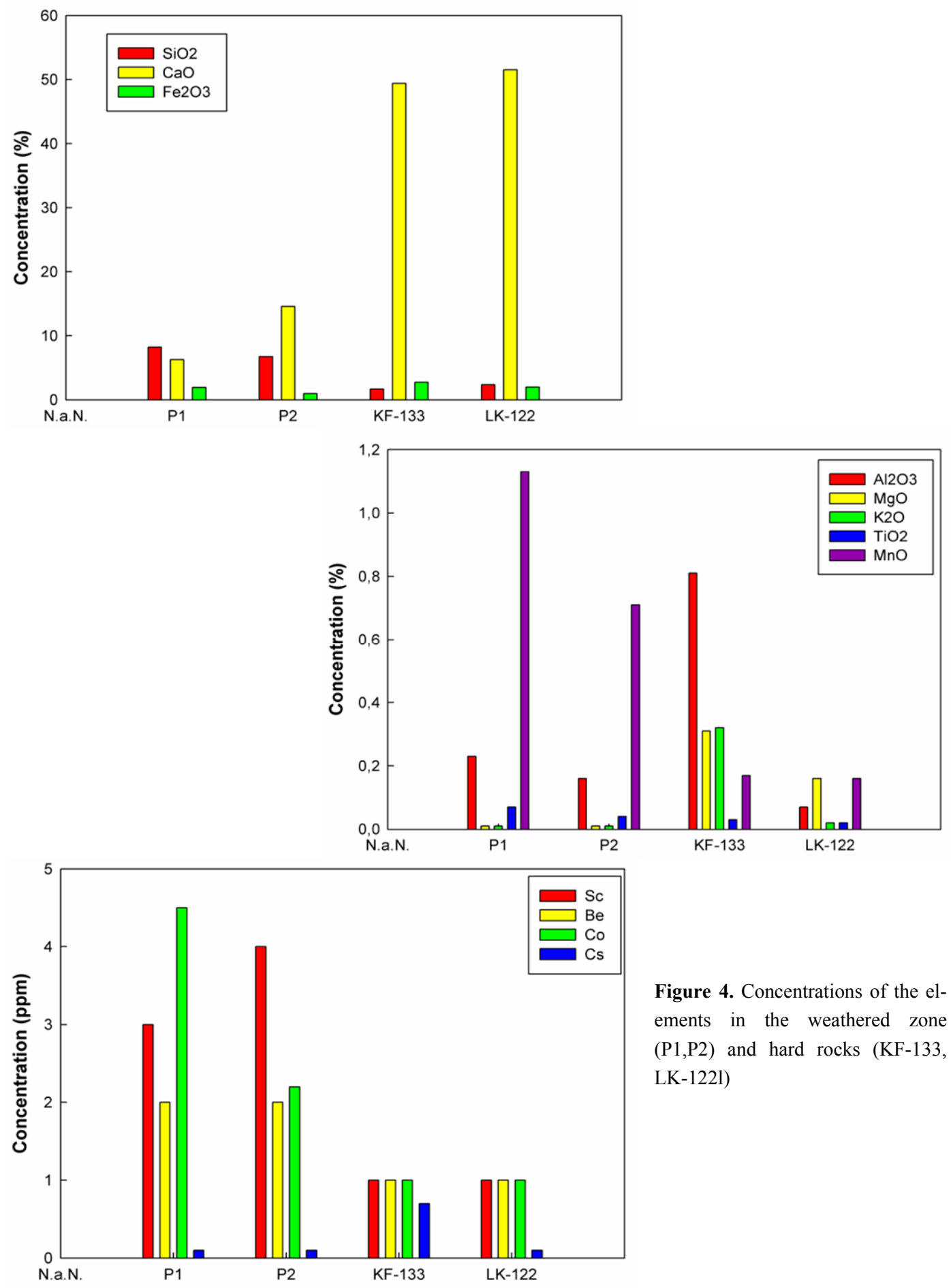

Figure 4. Concentrations of the elements in the weathered zone $(\mathrm{P} 1, \mathrm{P} 2)$ and hard rocks (KF-133, LK-1221) 
Vietnam Journal of Earth Sciences, 39(1), 14-26

Table 3. Measured concentrations of the rare earth and radioactive elements $(\mathrm{ppm})$ and weathering index $\left(\mathrm{V}_{\mathrm{i}}\right)$ for the collected samples

\begin{tabular}{|c|c|c|c|c|}
\hline Elements & $\mathrm{P} 1$ & $\mathrm{P} 2$ & KF-133 & LK-122 \\
\hline $\mathrm{La}$ & 39240 & 31100 & 798 & 823 \\
\hline $\mathrm{Ce}$ & 44600 & 36000 & 1340 & 1240 \\
\hline $\operatorname{Pr}$ & 3540 & 2990 & 122 & 104 \\
\hline $\mathrm{Nd}$ & 9830 & 8390 & 381 & 326 \\
\hline $\mathrm{Sm}$ & 903 & 783 & 43.6 & 39.0 \\
\hline $\mathrm{Eu}$ & 212 & 183 & 10.1 & 9.7 \\
\hline $\mathrm{Gd}$ & 583 & 494 & 26.8 & 24.8 \\
\hline $\mathrm{Tb}$ & 37.6 & 33.1 & 2.6 & 2.2 \\
\hline Dy & 122 & 112 & 11.0 & 9.0 \\
\hline Ho & 13.3 & 12.2 & 1.4 & 1.3 \\
\hline Er & 30.0 & 25.5 & 3.2 & 2.9 \\
\hline $\mathrm{Tm}$ & 3.6 & 3.3 & 0.5 & 0.4 \\
\hline $\mathrm{Yb}$ & 19.2 & 17.4 & 2.7 & 2.7 \\
\hline $\mathrm{Lu}$ & 1.9 & 1.8 & 0.4 & 0.3 \\
\hline$\Sigma$ REE & 99100 & 80100 & 2750 & 2580 \\
\hline${ }^{238} \mathrm{U}$ & 104.4 & 115 & 11,9 & 11,2 \\
\hline${ }^{232} \mathrm{Th}$ & 104 & 83.3 & 5,2 & 8,8 \\
\hline${ }^{40} \mathrm{~K}(\%)$ & 0,11 & 0.8 & 0.05 & 0,07 \\
\hline & 0.187 & 0.076 & 0.700 & 0.731 \\
\hline
\end{tabular}

Table 4. The average concentrations of the REE (ppm) in the ore bodies (Nguyen Tien Du et al., 2011)

\begin{tabular}{|c|c|c|c|c|c|c|c|}
\hline Element & $\mathrm{F} 4$ & F7 & F19 & F10 & F14 & F16 & F17 \\
\hline $\mathrm{La}$ & 9001 & 18925 & 14932 & 13735 & 8374 & 9017 & 7982 \\
\hline $\mathrm{Ce}$ & 11615 & 24371 & 19166 & 17686 & 10988 & 11821 & 10313 \\
\hline $\operatorname{Pr}$ & 1094 & 2286 & 1812 & 1677 & 1023 & 1098 & 967 \\
\hline $\mathrm{Nd}$ & 3186 & 6612 & 5237 & 4846 & 2954 & 3156 & 2808 \\
\hline Sm & 327 & 671 & 543 & 492 & 315 & 337 & 289 \\
\hline $\mathrm{Eu}$ & 169 & 334 & 267 & 246 & 158 & 169 & 141 \\
\hline Gd & 159 & 322 & 358 & 238 & 150 & 16 & 141 \\
\hline $\mathrm{Tb}$ & 18 & 36 & 29 & 27 & 17 & 18 & 16 \\
\hline Dy & 48 & 97 & 79 & 72 & 47 & 51 & 43 \\
\hline Ho & 7 & 15 & 12 & 11 & 7 & 8 & \\
\hline $\mathrm{Er}$ & 22 & 31 & 25 & 24 & 14 & 15 & 14 \\
\hline $\mathrm{Tm}$ & 2 & 5 & 4 & 3 & 3 & 3 & \\
\hline $\mathrm{Yb}$ & 7 & 14 & 11 & 10 & 7 & 7 & \\
\hline $\mathrm{Lu}$ & 1 & 2 & 2 & 2 & 1 & 1 & \\
\hline$\Sigma$ LREE & 25392 & 3199 & 41957 & 38682 & 23812 & 25598 & 22500 \\
\hline$\Sigma$ HREE & 264 & 522 & 520 & 387 & 246 & 119 & 230 \\
\hline$\Sigma$ LREE/ & 96 & 102 & 81 & 100 & 97 & 215 & 98 \\
\hline
\end{tabular}

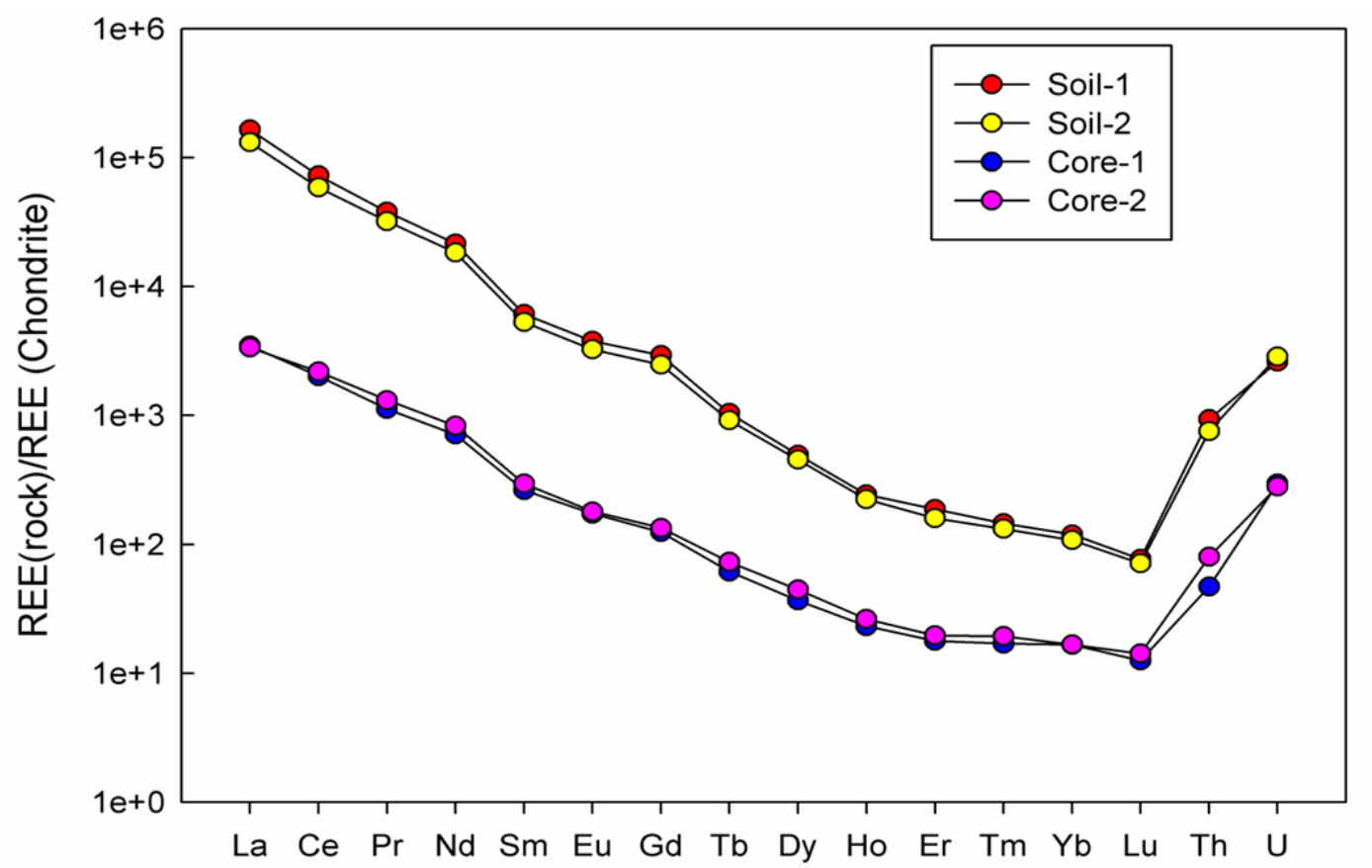

Figure 5. Patterns of the REE and radionuclides in the weathered and hard zones

The leaching and removal of intrusive formations by water activity and chemical processes led to the accumulation of igneous apa- tite, oxides, sulfides, and silicates. These phenomena were accompanied by replacement, decomposition, oxidation of the primary igne- 
Nguyen Dinh Chau, et al./Vietnam Journal of Earth Sciences 39 (2017)

ous minerals and crystallization of the secondary minerals. In consequence, the overlying weathered zone is enriched in insoluble phosphates, clays, iron and manganese bearing oxides containing REE, U, Th, Nb, Ta, Zr, Ti, V, $\mathrm{Cr}, \mathrm{Ba}$ and $\mathrm{Sr}$ (Hoatson et al., 2011). In the studied deposit, the REE minerals are parisite, bastnäsite, apatite, barite, fluorite and Celestine were observed. The picture of BSE (Back Scattered Electron) and the spectrum of energy diffraction scattered (EDS) of the parisite mineral are shown in the Figure 6 and Figure 7 respectively. The contribution of the REE in the parisite is (in wt.\%) 14.89 for $\mathrm{La}, 23.36$ for $\mathrm{Ce}$, 2.19 for $\mathrm{Pr}, 6.59$ for $\mathrm{Nd}$ and near 2 for remaining heavy REE.

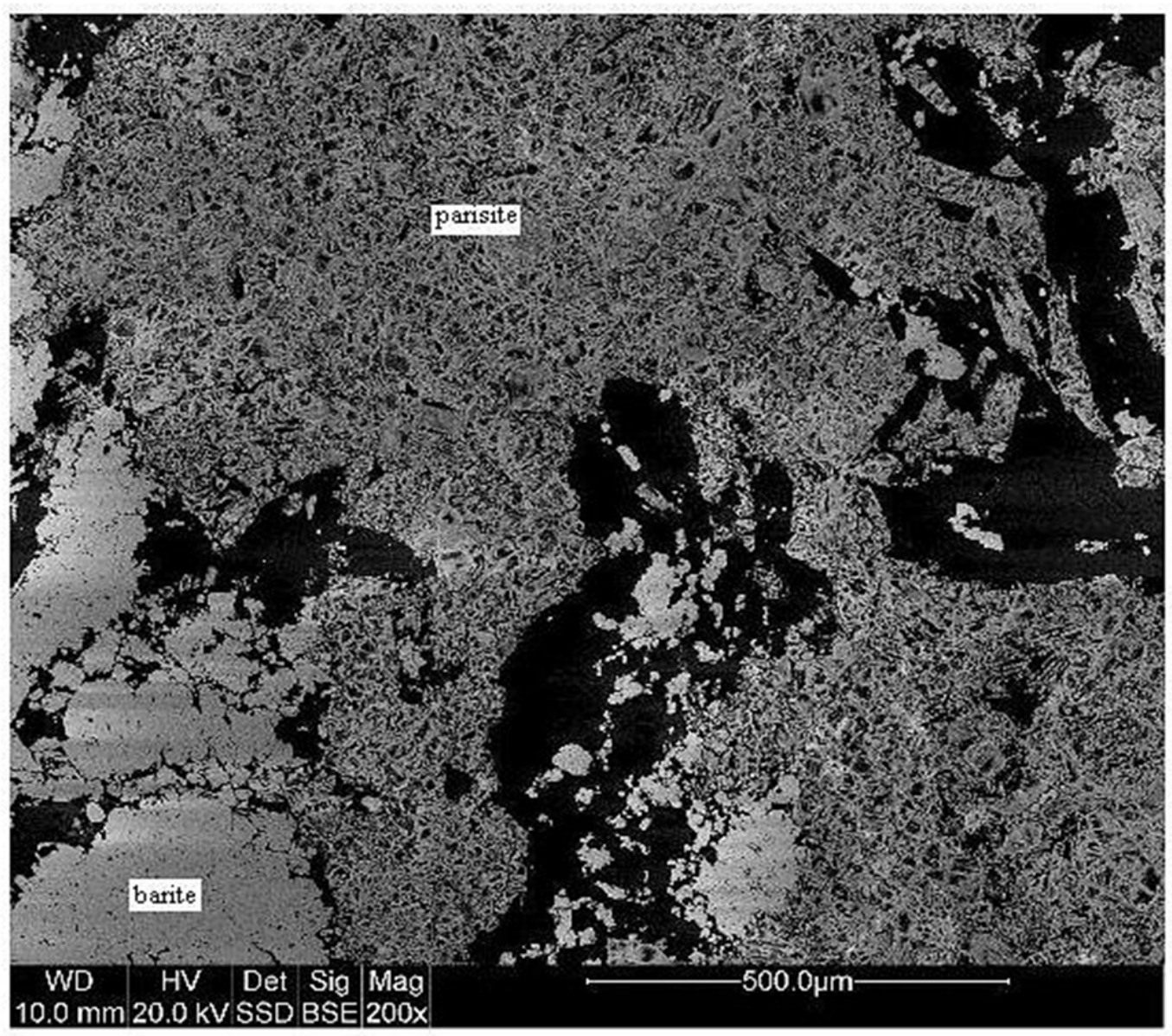

Figure 6. BSE picture

The mineralization of the stream and natural tap waters is equal to above two hundred $\mathrm{mg} / \mathrm{dm}^{3}$, the magnesium in tap and thermal waters are twice comparing to the stream ones (Table 5). The radium isotopes concentration in the stream water range from 100 to 300
$\mathrm{mBq} / \mathrm{dm}^{3}$, while in the thermal and natural tap waters amount only to several tens $\mathrm{mBq} / \mathrm{dm}^{3}$. The phenomenon is quite different for uranium isotopes, their concentration in the thermal water (groundwater) are equal to 110 and 78 $\mathrm{mBq} / \mathrm{dm}^{3}$ for $238 \mathrm{U}$ and $234 \mathrm{U}$ respectively. 
Vietnam Journal of Earth Sciences, 39(1), 14-26

This level is a few times higher than that in the stream and natural tap waters, which range near a few $\mathrm{mBq} / \mathrm{dm}^{3}$. Though the uranium and radium concentration in natural tap water are lower than permit maximum contaminant level for drinking water $\left(180 \mathrm{mBq} / \mathrm{dm}^{3}\right.$ for $238 \mathrm{U}$ and $185 \mathrm{mBq} / \mathrm{dm}^{3}$ for total radium isotopes (226Ra
+ 228Ra)), but significantly higher than the concentrations of these isotopes in Red River and tap waters (WHO 2006; Nguyen et al., 2016). Such high concentration of the uranium and radium in the water can be the diagnostic feature of the region, where the rock formations are rich in the natural radioactive elements.

Y:A-Piestrzynskil2016-07-21-WDoP 12 p1 002.spc

abel A: Chlorite [Nrm.\%= 38.86, 20.96, 34.83, 1.14, 3.84, 0.28]

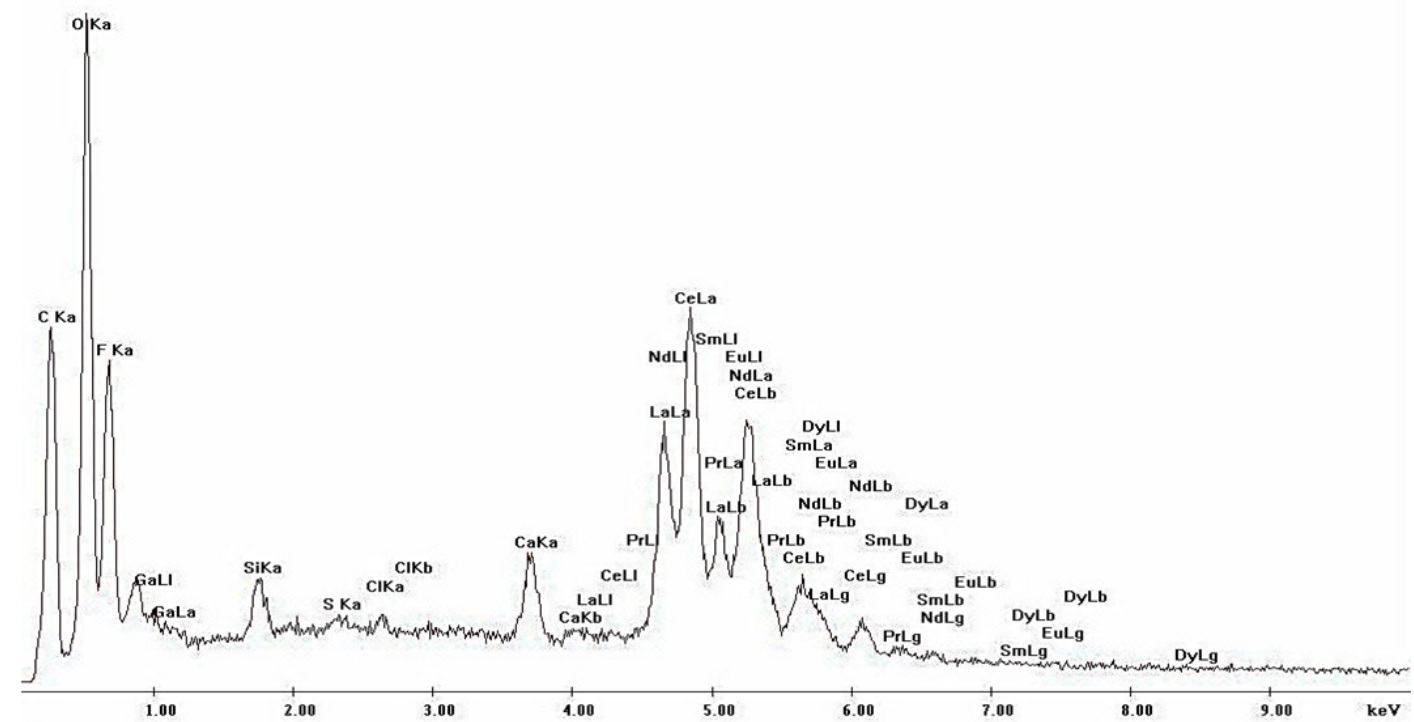

Figure 7. EDS spectrum of parisite

Table 5. Measured concentrations of main ions $\left(\mathrm{mg} / \mathrm{dm}^{3}\right)$ and natural radioactive isotopes $\left(\mathrm{mBq} / \mathrm{dm}^{3}\right)$ in the water samples

\begin{tabular}{lcccc}
\hline Water sample & $\mathrm{F} 3$ & $\mathrm{P} 1$ & $\mathrm{~F} 9$ & $\mathrm{TM}$ \\
\cline { 2 - 5 } $\mathrm{Na}^{+}$ & 3.4 & 2.7 & 2.3 & 10.6 \\
$\mathrm{~K}^{+}$ & 1.6 & 0.7 & 4.2 & 6.9 \\
$\mathrm{Ca}^{2+}$ & 38.0 & 54.8 & 37.0 & 99.8 \\
$\mathrm{Mg}^{2+}$ & 3.5 & 5.2 & 9.5 & 14.4 \\
$\mathrm{Sr}^{2+}$ & 0.9 & 0.8 & 2.5 & 8.9 \\
$\mathrm{Cl}^{-}$ & 5.1 & 4.2 & 3.4 & 4.2 \\
$\mathrm{SO}_{4}{ }^{2-}$ & 3.0 & 2.3 & 6.3 & 184 \\
$\mathrm{HCO}_{3}^{-}$ & 137 & 187 & 159 & 185 \\
$\mathrm{TDS}_{\mathrm{pH}}$ & 206 & 271 & 256 & 560 \\
${ }_{226} \mathrm{Ra}$ & 7.8 & 8.0 & 8.0 & 7.9 \\
${ }^{228} \mathrm{Ra}$ & 123 & 336 & 29 & 12 \\
${ }^{234} \mathrm{U}$ & 105 & 309 & 33 & 18 \\
${ }^{238} \mathrm{U}$ & 14 & 38 & 28 & 78 \\
$\mathrm{Hydro}-$ chemical type of water & 21 & 16 & 30 & 110 \\
& $\mathrm{HCO}_{3}-\mathrm{Ca}$ & $\mathrm{HCO}_{3}-\mathrm{Ca}$ & $\mathrm{HCO}_{3}-\mathrm{Ca}-\mathrm{Mg}$ & $\mathrm{HCO}_{3}-\mathrm{SO}_{4}-\mathrm{Ca}$ \\
\hline
\end{tabular}


Nguyen Dinh Chau, et al./Vietnam Journal of Earth Sciences 39 (2017)

\section{Conclusions}

The Dong Pao deposit is rich in light rare earth elements such as $\mathrm{La}, \mathrm{Ce}, \mathrm{Pr}$ and $\mathrm{Nd}$, their total concentration approximates 10 wt. $\%$ in the weathered zone.

The mass contents of uranium and thorium in the studied REE deposit are comparable reaching about $0.01 \mathrm{wt} . \%$ and $0.001 \mathrm{wt} . \%$ in the upper weathered and lower limestone and dolomite zones respectively.

The pattern of $U$, Th and REE in the ore bodies occurring in the weathered zone is similar to that in the lower zone, but in the weathered zone the contents of these elements are higher by a few orders of magnitude in comparison with the lower dolomite and limestone zone.

The $\Sigma$ LREE/ $\Sigma$ HREE ratio suggests that the mineralization processes in the Dong Pao deposit could be described as follow: the REE, uranium and thorium elements firstly came from the Mantle together with the Dong Pao alkali syenite and porphyritic syenite; next, the ores were precipitated from hydrothermal fluids and finally enriched by the surface weathering processes.

The radium and uranium concentration in the surface and natural tap waters are a consequence of the leaching processes of the elements from the weathered rocks and can be a geological indicator in the prospecting of deposits rich in the natural radionuclides.

This work was partly funded by the Bilateral Project between HUMG and AGH-UST Kraków, Poland No. 01/2012/HD-HTQTSP and AGH-UST Foundation Projects No 11.11.220.01, 15.11.220.717.

\section{References}

Bureau Veritas Canada, 2015. Certificate of analysis No KRA 15000229.1

Curtis N., 2011. Lynas Report. https://www.lynascorp.com/Pages/Reporting-centreAnnual-report.aspx.

Damascena K.R., et al., 2015. Rare-earth elements in uranium deposits in the municipaliity of Pedra, Per- nambuco, Brazil. J. Radioanal. Nucl. Chem. 304, 1053-1058.

Dovzikov A.E., 1965. Geology of North Vietnam, explanation and interpretation for the Geological Map of North Vietnam. Vietnam Geol. Depart. (in Russian).

Faure, M., Lepvrier, C., Van Nguyen, V., Van Vu, T., Lin, W., \& Chen, Z., 2014. The South China BlockIndochina collision: where, when, and how? Journal of Asian Earth Sciences, 79, 260-274.

Fromaget J., 1941. Geological structure, deposits related to tectonics of Indochina. Indochina Geol. Biul. XXVI(2), (in France).

Fromaget J., Saurin E., 1952. Geological map of Indochina 1:200.000. National Geograph Institute of France.

Halpin J.A., Tran T.H., Lai C.K., Meffre S., Crawford A.J., Zaw K., 2015. U-Pb zircon geochronology and geochemistry from NE Vietnam: A "tectonically disputed" territory between the Indochina and South China blocks. Gondwana Research, http://dx.doi.org/10.1016/j.gr.2015.04.005.

Hoatson D.M., Jaireth S., Miezitis Y., 2011. The major Rare-Earth element deposits of Australia: Geological setting, exploration and resources. Australian Government, Geoscience Australia, 193.

Hornig-Kjarsgaard I., 1998. Rare earth elements in sovitic carbonatites and their mineral phases. J. Petrology, 39, 2105-2121.

Hou B., 2005. Heavy mineral sands potential of the Eucla Basin in South Australia - a world-class palaeobeach placer province. MESA Journal, 37, 4-12.

Jodłowski P., Kalita S., 2010. Gamma-Ray Spectrometry Laboratory for high-precision measurements of radionuclide concentrations in environmental samples. Nukleonika, 55(2), 143-148.

Kušnir I., 2000. Mineral resources of Vietnam. Acta Montanista Slovaca, 5(2), 165-172.

Le Khanh Phon, Bui Dac Dung, Nguyen Dinh Chau, Tibor Kovacs, Nguyen Van Nam, Dong Van Hao, Nguyen Tai Son, Vu Thi Minh Luan, 2015. Estimation of effective dose ratek caused by radon and toron for inhabitants living in rare earth field in north Wietnam (Lai Chau province). J. Radioanal. Nucl. Chem, 306, 309-316.

Liu Y., Hu Z., Gao S., Günther D., Xu J., Gao C., Chen H., 2008. In situ analysis of major and trace ele- 
Vietnam Journal of Earth Sciences, 39(1), 14-26

ments of anhydrous minerals by LA-ICP-MS without applying an internal standard. Chem. Geol. 257, 34-43.

Nguyen Dinh Chau, Niewodniczański J., Dorda J., Ochoński A., Chruściel E., Tomza I., 1997. Determination of radium isotopes in mine waters through alpha- and beta-activities measured by liquid scintillation spectrometry. J. Radioanal. Nucl. Chem., 222(1-2), 69-74.

Nguyen Dinh Chau, Le K.P., Jodłowski P., Pieczonka J., Piestrzyński A., Duong V.H., Nowak J., 2016. Natural Radioactivity at the Sin Quyen Iron-OxideCopper-Gold Deposit in North Vietnam. Acta Geophys, 64(6), 2305-2321.

Nguyen Tien Du, et al., 2011. Report of the supplementary geological prospecting surveys at the Rare Earth Elements at Dong Pao Deposit, Ban Giang District, Lai Chau province, Nort-Weast Vietnam. Archive at the Geological Division VIMICO, Lai Chau. (in Vietnames), 215.

Pham Ngoc Can, Ishiyama D., Tran Tuan Anh, Sera K., 2011. Mineralogical and geochemical characteristics of rare metals-bearing Na Bop, Lung Hoai, Na Son and Sin Quyen base metal deposits, North Vietnam. NMCC Annual Report 18, 49-55.

Rösler H.J, Lange H., 1976. Geochemical Tables, Edition Leipzig, 468.

Tran Van Tri 2011. Geology and Earth Resources of Vietnam [in] Vu Khuc (ed). General Dept. of Geology and Minerals of Vietnam, Hanoi, Publishing House for Science and Technology, 634.

Tran Trong Hoa, Tran Tuan Anh, Pham Thi Dung, Tran Quoc Hung, Bui An Nien, Tran Van Hieu, Pham Ngoc Can, 2010. Useful elements accompanying with the $\mathrm{Pb}-\mathrm{Zn}$ and $\mathrm{Cu}$ deposits in the North Vietnam. Vietnam Journal of Earth Sciences, 32(4), 289-298. (in Vietnamese).

WHO 2006. Guidelines for Drinking-water Quality, First Addendum to Third Edition, V Recommendations. New Jork, 595.

Żelaźniewicz A., Tran T.H., Larionov A.N., 2013. The significance of geological and zircon age data derived from the wall rocks of the Ailao Shan-Red River shear zone, NW Vietnam. J. Geodynamics, 69, 122-139. 